\title{
ВОСПРИЯТИЕ ПОСЛЕДУЮЩИМИ КУЛЬТУРАМИ ПАМЯТНИКОВ ПРЕДЫДУЩИХ. ИСТОРИКО-КУЛЬТУРНЫЕ ОСОБЕННОСТИ РАЗМЕЩЕНИЯ ХРАМА В КОТЛОВИНЕ СОРГА́ (ХАКАСИЯ)
}

\author{
(C) 2020 г. Игорь Леонидович Кызласов ${ }^{1}$
}

${ }^{1}$ доктор исторических наук, ведущий научный сотрудник, Институт археологии РАН, г. Москва, Россия. E-mail: kyzlasovil@mail.ru

\begin{abstract}
Аннотация. В Южной Сибири древние памятники, созданные из камня, стали обязательной частью пейзажа. Остатки средневековья надо осознавать среди них. На писаницах, могильниках и храмовых центрах Хакасии прослежено как тогда воспринимались памятники предыдущих культур. Рисунки, а затем тамги и молитвенные надписи средневековья не нарушают петроглифы былых времен, значит, сохранялись горные культы. Курганы VI-VIII вв. продолжают кладбища II в. до н.э. - V в. н.э., видно, осознавались кровные связи с предками. В VIII в. манихейский храм возвели в долине, где по XX в. оставались нетронутыми 14 скульптур и около 15 менгиров. Храм действовал среди языческих идолов, ближайшие были от него в 100-140 м. Достигнув Енисея, манихейство включило в свою религиозную практику руническую письменность, а вместе с нею и комплекс мировоззрения, сохранявшего почитание памятников предков. Взаимное проникновение новых и местных верований сформировало особое религиозное направление - северное, сибирско-тюркское манихейство.
\end{abstract}

Ключевые слова: археология, Хакасия, средневековье, отношение последующих культур к предыдущим, сибирско-тюркское манихейство

\section{КЕЙІНГІ МӘДЕНИЕТТЕРДІН БҰРЫНҒЫ ЕСКЕРТКІШТЕРДІ ҚАБЫЛДАУЫ. СОРГА (ХАКАСИЯ) ҚАЗАНШҰНҚЫРЫНДАҒЫ ҒИБАДАТХАНА ОРНАЛАСУЫНЫН ТАРИХИ-МӘДЕНИ ЕРЕКШЕЛІКТЕРІ}

\section{Игорь Леонидович Кызласов ${ }^{1}$}

${ }^{1}$ тарих ғылымдарының докторы, жетекші ғылыми қызметкер, PҒА Археология институты Москва, Ресей. E-mail: kyzlasovil@mail.ru

Аннотация. Сібірдің оңтүстігінде тастан жасалған ежелгі ескерткіштер табиғат көрінісінің міндетті бөлігіне айналды. Олардың арасында орта ғасырлардың қалдықтары бар екендігі де ескерілуі керек. Жазбаларда, көмбелерде және Хакасияның храм орталықтарында онда алдыңғы мәдениет ескерткіштері қалай қабылданғандығы қадағаланған. Орта ғасырлардағы суреттер, содан кейін тамғалар мен дұға жазбалары бұзылмайды, өткен дәуірдің петроглифтері тау культтері сақталғанын білдіреді. VIVIII ғғ. қорғандар б.д.д. II ғ. - б.д.д. V ғ. бейіттерді жалғастырады, бабалармен қандық байланысты сезінді. VIII ғасырда аңғарда тұрғызылған манихей ғибадатханасынан XX ғ. 14 мүсін және шамамен 15 қадатастар қол тимеген қалында қалды. Храм пұтқа табынушы пұттардың арасында жұмыс істеді, оның ең жақыны 100-140 м. Енисей- 
Кызласов И.Л. Восприятие последующими культурами памятников предыдущих...

ге жетіп, манихейизм өзінің діни тәжірибесіне руникалық жазуды енгізді, сонымен бірге ата-бабалар ескерткіштерін кұрметтейтін дүниетаным кешені болды. Жаңа және жергілікті нанымдардың өзара енуі ерекше діни бағытты - Солтүстік, Сібір-түркі манихейлігін қалыптастырды.

Түйін сөздер: археология, Хакасия, орта ғасырлар, кейінгі мәдениеттердің алдыңғыға қатынасы, Сібір-түркі манихейизмі

\title{
PERCEPTION OF PREVIOUS MONUMENTS BY SUBSEQUENT CULTURES. HISTORICAL AND CULTURAL FEATURES OF THE LOCATION OF THE TEMPLE IN THE BASIN OF SORGÁ (KHAKASSIA)
}

\author{
Igor L. Kyzlasov ${ }^{1}$ \\ ${ }^{1}$ Doctor of Historical Sciences, Leading Researcher, \\ Institute of Archaeology of the Russian Academy of Sciences, \\ Moscow, Russia. E-mail: kyzlasovil@mail.ru
}

\begin{abstract}
In Southern Siberia, ancient monuments made of stone have become a mandatory part of the landscape. The remnants of the Middle Ages must be understood among them. On the carvings, burial grounds and temple centers of Khakassia, it is traced how monuments of previous cultures were perceived then. Drawings, and then tamgas and prayer inscriptions of the Middle Ages do not violate, petroglyphs of former times, therefore, mountain cults were preserved. Mounds of the $6^{\text {th }}-8^{\text {th }}$ centuries continue cemeteries of the $2^{\text {nd }}$ century $\mathrm{BC}-5^{\text {th }}$ century $\mathrm{AD}$, it can be seen that blood connections with ancestors were realized. In the $8^{\text {th }}$ century, the Manichaean temple was erected in the valley, where up to the $20^{\text {th }}$ century 14 sculptures and about 15 menghirs remained intact. The temple was among pagan idols, the closest were at 100-140 m distance. Having reached the Yenisey, Manichaeism included runic writing in its religious practice and together with it a complex of worldview that preserved the veneration of ancestral monuments. The mutual penetration of new and local beliefs formed a special religious direction - northern Siberian-Turkic Manichaeism.

Keywords: archaeology, Khakassia, Middle Ages, relation of subsequent cultures to previous, Siberian-Turkic Manichaeism
\end{abstract}

\section{Введение}

Археологическая наука в России началась с исследовательских раскопок первой русской экспедиции Д. Г. Мессершмидта 1-6 января (1217 января по новому стилю) 1722 г. на землях лишь за три года до этого присоединенной Хакасии [Кызласов Л.Р., 1962, с. 51, 52; Савинов, 2017 , с. 87-89].

За три века в археологии Южной Сибири сделано много. Однако остаются не осознанными значимые для профессионального восприятия отличия этих земель. Как на всём Саяно-Алтайском нагорье, в ХакасскоМинусинской котловине повсюду на виду стоят древние, устроенные из камня или отмеченные монолитами курганы, изваяния, стелы и менгиры, на горах высечены наскальные рисунки и рунические надписи, высятся крепостные стены. Трудно найти земли, где было бы столь большое число и такое разнообразие зримых памятников древности. Они стали повсеместной приметой здешнего пейзажа, непременной частью окружающей природы.

Средневековые древности Южной Сибири приходится воспринимать среди памятников предшествующих культур - зримых не только для нас, но бывших частью окружавшего 
ландшафта и для создателей средневековых культур и любого их объекта. Понимание этого должно отличать сознание археолога-медиевиста, изучающего Саяно-Алтайское нагорье.

Казалось бы, в этом он не отличается от иных специалистов: каждая из последующих культур региона неизбежно воспринимала памятники всех предыдущих. Однако в нашей науке все еще не поставлена сама проблема восприятия последующиими культурами памятников предьдущих. Проследим археологические свидетельства и особенности выражения этого закономерного для Южной Сибири культурного явления.

Нет данных о том, как воспринимались потомками курганы. Касательно древности можно видеть отношение к примечательным и весьма многочисленным для Среднего Енисея одиночным монументам местных форм: изваяниям, стелам, менгирам. В средневековье явно проступает связь древнехакасских культур с другой категорией характерных археологических объектов - с писанными скалами.

Переиспользование монументальных памятников в древности

Хорошо известно массовое вторичное использование плит и плоских стел, несущих сакральные образы, в качестве строительного материала для могил окуневской культуры эпохи ранней бронзы. Так, в могильнике Черновая VIII в разном положении встречено 50 крупных и мелких обломков плит с изображениями (47 из них в курганах [Леонтьев, 1980, с. 27]), в том числе 15 с личинами. Шесть из них стали частью покрытия могил, еще шесть пошло на стенки могил, об- ломки одной стелы были и стенкой, и среди покрытия; дважды куски одной стелы найдены в разных могилах, две стали стенками одного погребального ящика и т.д. [Вадецкая, 1980, с. 81, В; Леонтьев и др., 2006, № 113-119, 123, $124,126,130-132]$. Ситуация обычна и для других комплексов - разбитая на части стела стала покрытием и частью стенки ящика могилы в пос. Усть-Бюрь [Кызласов Л.Р., 1986, с. 273,274 , рис. $112,183-185]$ (рис. 1). Каталог изваяний и стел, известных к началу XXI в., включает 13 стел из Черновой VIII, дополняя их 32 такими находками в 11 могильниках и курганах [Леонтьев и др., 2006].

Исследователи старшего поколения, работавшие в 1950-1980 гг., видели в этом пренебрежение к святыням былых времён, относя их «к эпохе, предшествующей афанасьевской культуре», «учитывая чуть ли не неолитические их истоки» [Киселёв, 1962, с. 56]. Отмечалось разнородное и многократное нанесение изображений, восходящая к неолиту таёжноохотничья и сменившая ее степная скотоводческая символика [Шер, 1980 , с. $216-229,232,233$; 2006]. Исследовавший святилища с изваяниями Л. Р. Кызласов на широком фоне привел доводы их принадлежности к началу III тыс. до н.э. - к поздненеолитическому доафанасьевскому периоду, назвав его тазминской культурой [Кызласов Л.Р., 1986, с. 168-187]. Аналогии типу святилищ нашлись, прежде всего, в неолите и мезолите Приангарья, а также в более ранних памятниках иных земель [Кызласов Л.Р., 1992]. Широк в неолите и культ менгиров. В IV - начале III тыс. до н.э. нашлись подобия типажам изображенных атрибутов, пластике изва- 
Кызласов И.Л. Восприятие последующими культурами памятников предыдущих...

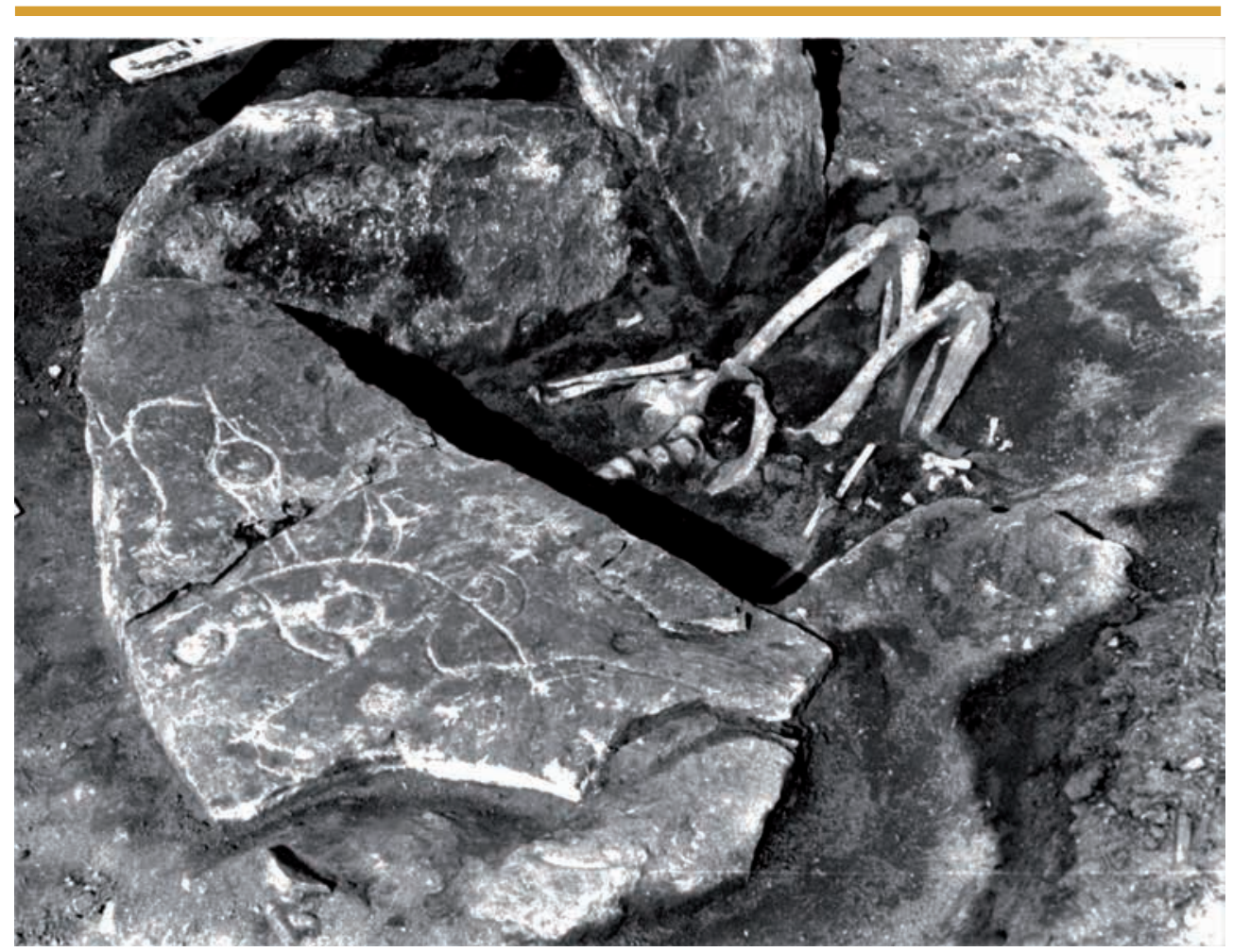

Рис. 1. Окуневская культура. Усть-Бюрь, ограда 5, погребение 1. Обломки стель с личиной, переиспользованной в качестве перекрытия и стенки каменного ящика (по: [Кызласов Л.Р., 1986, рис. 185])

Fig. 1. Okunev culture. Ust-Byur, fence 5, burial 1. Stele fragments with a guise reused as a slab and stone box wall (by: [Kyzlasov L.R., 1986, Fig. 185])

яний, их композиционным, образносюжетным, стилистическим особенностям.

Ныне это культовое искусство, включая скульптурные изваяния и вторично использованные плиты и стелы, относят к окуневской культуре. Делается это по косвенным данным, полученным в захоронениях. Связанные с изваяниями святилища после Л. Р. Кызласова никто не исследовал ${ }^{1}$. Такие работы могли бы дать прямые датирующие материалы и объяснить, отчего при раскопках 19 стоявших in situ объектов «ни разу не обнаружены предметы или обломки сосудов афанасьевского и окуневского типов» [Кызласов Л.Р., 1986, с. 87-135, 171].

Датировки этого явления, предложенные Л. Р. Кызласовым, оказались подтверждены: начало окуневской культуры по радиоуглероду продолжает удревняться: до $\mathrm{XXV}$, XXVI, а то и XXVII в. до н.э. [Поляков, Святко, 2009, с. 28,29 , рис. 4,12 ; Поляков, 2017; 2019, с. 169, рис. 4; см.: Соколова, 2011]. Неолитические корни окуневского искусства увиде-

${ }^{1}$ Своеобразие личин и антропоморфных образов признается несвойственным афанасьевской культуре и приенисейскому неолиту. В них склонны видеть дальневосточный импульс [Соколова, 2009, с. 19, 20], что, по сути, развивает наблюдения С. В. Киселёва [1962, с. 56, 57, рис. 2] и Л. Р. Кызласова [1986, с. 176, рис. 111] о сходстве с образами культуры Яньшао раннего неолита. 
ны М. Л. Подольским [1997, с. 194, 200]. Подтвердилось восточносибирское направление поисков: керамика и, частью, петроглифы указывают на неолитические корни, «локализованные между Енисеем и Байкалом» [Cоколова, 1995; 2007, с. 48, 50, 51].

Задача статьи не требует решения этого вопроса. Факты вторичного использования обсуждаемых плит, стел и изваяний в памятниках последующих культур хорошо известны археологам [Кызласов Л.Р., 1986, с. 185; Кузьмин, 1995]. Сводок данных по культурам нет, выберем сведения из каталога изваяний и стел [Леонтьев и др., 2006].

В раскопанных курганах андроновской культуры известны только шесть вторично использованных таких стел. Пять служили перекрытием погребений [Вадецкая, 1980, с. 81, № 152; Леонтьев и др., 2006]. Однажды плита использована для перекрытия погребального ящика, а изваяние найдено в жилище карасукской культуры [Леонтьев и др., 2006, № 133, 273].
Собственно карасукские плиты с петроглифами также изредка служили перекрытиями и стенками могил [Филиппова, 1990].

В эпоху бронзы лишь плоские формы культовых изображений вторично использовались для сооружения подкурганных гробниц. В раннем железном веке в большом числе употреблялись только первобытные монолиты. Полнообъемные изваяния и стелы устанавливались в курганных конструкциях тагарской культуры. Помимо лежащих скульптур, в названном каталоге находим 94 случая [Леонтьев и др., 2006].

Особенно часто изваяния были стояками (рис. 2), плоские стелы с личинами для этого использовались редко [Вадецкая, 1980, с. 87, № 85; Кызласов Л.Р., 1986, рис. 71, 84, 8991 и др.; Леонтьев и др., 2006, рис. 2, 28-31, 35-38]. Изредка стелы были стенками ограды и покрытиями погребений [Вадецкая, 1980, № 32, 120; Леонтьев и др., 2006, № 32, 205]. На одном кургане бывает по два, а как-

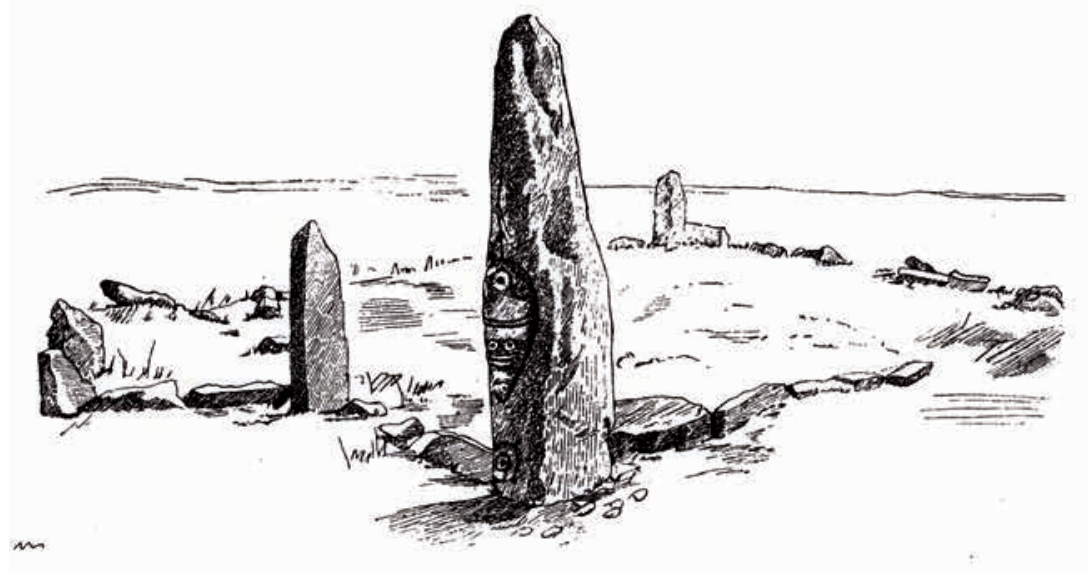

Рис. 2. Тагарская культура. Древнее изваяние в ограде кургана Чалгыс-Оба на p. Уйбam (no: [Appelgren-Kivalo H., 1931, Abb. 294])

Fig. 2. Tagar culture. The ancient sculpture in the fence of the mound Chalgys-Oba on the river Uibat (by: [Appelgren-Kivalo, 1931, Abb. 294]) 
Кызласов И.Л. Восприятие последующими культурами памятников предыдущих...

то раз - три изваяния [Леонтьев и др., 2006, № 165-168, 194, 195, 202, 203, $284,285]$, однажды оно стояло на вершине кургана переходного тагарскоташтыкского (тесинского) этапа [Кызласов Л.Р., 1986, с. 140, рис. 77; Леонтьев и др., 2006, № 112]. Один раз изваяние вкопано вершиной вниз [Леонтьев и др., 2006, № 165].

Столь массовое использование изваяний с рельефными личинами, в изначальной древности символизировавших вертикальный горный образ одухотворенного мира [Кызласов Л.Р., 1986, с. 188-241], отвечает семантике самих тагарских курганов и менгиров. Направленное на стороны света подквадратное сооружение воспроизводило форму обитаемого мира, а плиты ограды изображали горные хребты на краях мира. Менгиры по углам, а с развитием тагарской культуры - и по сторонам ограды, означали священные вершины на этих предельных хребтах. У каждой почитаемой горы был свой дух [Кызласов И.Л., 1987;
1989, с. 201-207]. Учитывая такие воззрения, возможно правдоподобно объяснить систематическое использование в курганных конструкциях древнейших изваяний, наделенных фантастическими ликами.

Не учтены многочисленные переиспользованные в тагарских оградах одновременные изваяниям менгиры. Таков камень входа Большого Салбыкского кургана. Скульптурно обработанный, он имеет фаллическую форму, характерную для изваяний с личинами, но несопоставимую с иными стояками сибирской пирамиды (рис. 3).

В таштыкской культуре, открывающей на Среднем Енисее эпоху средневековья, поминальный культ связан с установкой рядами необработанных стел. Каждая из них символизировала окаменевшую душу умершего [Кызласов И.Л., 1975]. Несмотря на это, в таких рядах шесть раз встречены обсуждаемые здесь изваяния [Леонтьев и др., 2006, № 9, 54, 78, 160,

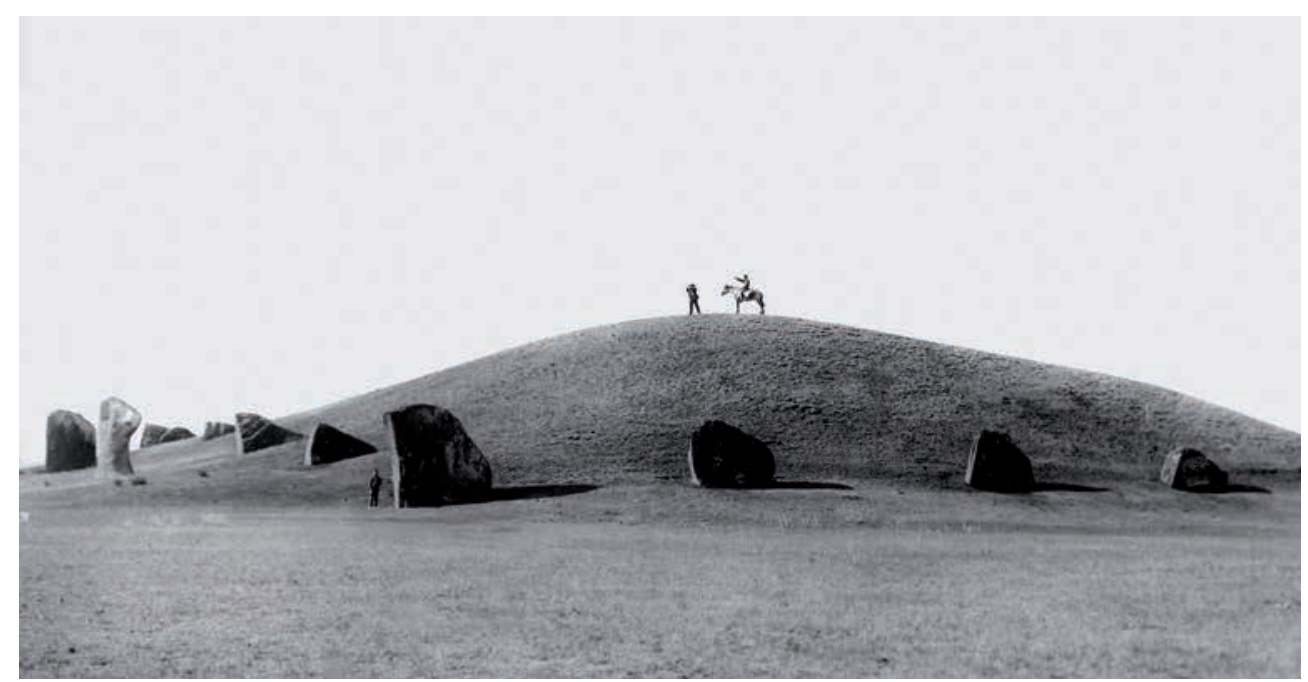

Рис. 3. Тагарская культура. Большой Салбыкский курган. Вид до раскопок, начало ХХ в. Слева - камни входа. Фото Минусинского музея

Fig. 3. Tagar culture. Big Salbyk mound. View before excavation, beginning of 20th century. On the left-stones of the entrance. Photo of the Minusinsk Museum 
288], а одна из них вкопана перевернутой [Леонтьев и др., 2006, № 213]. В качестве таштыкских поминальных стел вторично использовались и менгиры бронзового и раннего железного веков. Они еще никем не выделены.

Для археологии Саяно-Алтая насущен вопрос, каким было восприятие памятников былых времен в средневековых культурах.

Наложение средневековых памятников на святилища бронзового века

Осознавая проблему, практически нечего сказать об обыденных сфеpax жизни средневековья. В Южной Сибири господствует курганная археология - примат кочевниковедения поныне препятствует становлению поселенческой тематики. Меж тем, наземные срубные жилища в раннем железном веке здесь были обыденностью. Их самобытные формы сохранялись по всему Саяно-Алтаю вплоть до живых культур коренных народов [Кызласов И.Л., 2011, с. 38-71].

В Хакасско-Минусинской котловине лишь средневековые крепостисве (хак. сіве), каменными стенами отсекающие у скал спасительные вершины, предоставляют для наших поисков формальные возможности. Они подчинены единым принципам обороны, архитектурным канонам и мерным величинам (модуль $40 \mathrm{~cm}$ ), но не могут относиться к обыденным объектам, т.к. помимо военных могли отвечать и сакральным нуждам.

Их расположение частенько совпадает с размещением на макушках гор былых святилищ бронзового века. Однако, вопреки бытующему мнению, стены на горах не имеют ни прямой, ни преемственной связи с древними объектами. В средневековье такие культовые места нигде уже не имели внешних признаков. Они и ныне не являются зримыми памятниками - их находят только благодаря средневековым каменным стенам, привлекающих археологов на вершины сопок. Наслоения эпохи бронзы случайно попадали на площадки значительно более поздних оборонительных сооружений.

Поставленные поперек склонов, стены горных крепостей препятствуют естественному сползанию с вершины любых предшествующих отложений. Потому и лежат у их подножия остатки всех местных культур эпохи бронзы: афанасьевской, окуневской, карасукской, даже редкой для этих мест андроновской. Для датировки стен копать надо не у внутренней, а у внешней поверхности кладки - тогда будет ясно, на что она поставлена. Разговор об этом с М. Л. Подольским в 1999 г. привел к такой расчистке на изучавшемся им сіве Чыланныг-Таг (хак. Чыланнығ тағ, гора Змеиная). Тогда из-под стены вышла керамика эпохи бронзы, а раскоп 2006 г. показал перекрывание кладкой укрепления одного из ранних жилищ (№ 11). В одном из них, кроме черепков бронзового века, найден фрагмент донца средневекового сосуда и кусок кованного железного стержня (наблюдения автора при посещении памятника и рассказ М. Л. Подольского; ср.: [Подольский, 2001; 2008, с. 144, рис. 80, 81, 83a, 84a, 99a-б].

При строительстве этой крепости выше укреплений была срыта бывшая там почва, оказавшаяся культурным слоем ритуального поселения эпохи бронзы. Из перемешенного грунта насыпали горизонтальную 
Кызласов И.Л. Восприятие последующими культурами памятников предыдущих...

террасу с отвесным внешним краем, облицованным каменной кладкой. Реконструируемый каменный парапет [Подольский, 2001, с. 124, 125, рис. 85] необязателен. Не имевшие дополнительных укреплений боевые площадки, выравнивающие крутизну особо наклонных склонов, отчего напольная сторона оформлялась каменной кладкой, вписанной в линию стен, - часто устраивались на средневековых сіве ${ }^{2}$. Они мне известны на Хара-Таге (Хара тағ, Арга), верхней стене Онло (Оңло/Оңно тағ, Сундук), на Оглахтах (Ағлах тағ) и на других крепостях. Нашими исследователями они не фиксируются, но есть в старых изданиях [Appelgren-Kivalo, 1931, Abb. 95, a-b]. О средневековой принадлежности сіве Чыланныг-Таг говорит и северный участок стены, выложенный характерным зигзагом.

Археологи открыли не горные крепости эпохи бронзы. Благодаря средневековым укреплениям (вновь скажу: подчиненных единым канонам), они обнаружили существование на горах святилищ бронзового века - всей свиты культур того времени, существовавших на Среднем Енисее с конца IV-III по начало I тыс. до н.э. Осталось отыскать подобные объекты на горах, не имеющих внешних признаков. Письменные источники указывают, что крепости-сіве использовались по прямому назначению еще в XVII в.

Восприятие древних памятников проявляют средневековые долинные крепости Хакасии. Они длинны- ми стенами и рвами закрывают устья логов и внутренние долины горных массивов. Таковы, например, Борбакова крепость (Белый город русских источников XVII в.) на Чёрном Июсе (Хара Ӱ̈̈с) и Оглахтинская крепость на Енисее (Ким суғ), укрепления которых протянулись на 4 и 25 км соответственно. Стена Оглахтинской крепости трижды обходит, оставляя внутри обороняемых земель, курганы тагарской культуры (пункты Оглахты I, II и IV), что в целом сопоставимо с размещением средневековых курганов древнехакасской аскизской культуры. Показательно, что в Моховском логу средневековая стена перерезает, разрушая, малозаметные земляные курганчики карасукской культуры эпохи бронзы [Кызласов Л.Р., 1969, c. $245 ; 1970$, c. 197,$199 ; 2017$ a, c. 141 , 142; 2017б, с. 131; Филиппова, 1974, рис. 1]. Явную преемственность показывает Омай-Тура: средневековая стена, закрывающая выход на берег из трубы Енисея, использовала овалованные укрепления раннего железного века [Длужневская, 1989, с. 93-94, рис. 2].

Восприятие древних памятников в культовой сфере средневековья

Восприятие памятников предшествующих культур в культовой жизни средневековья отражено многообразно. Рассмотрим три рода древностей: писаницы, курганные могильники и храмовые центры.

Сделанные в конце XX в. открытия разделяют южносибирское

${ }^{2}$ Скрываться не было нужды: стрельба на крутую гору редко превышала 160 м, а сверху вниз достигала 400 м [Медведев, 1966, с. 30]. Атакующий сіве неизбежно сбивал дыхание, снижая возможность прицеливания. Лук мог им применяться лишь на самой короткой дистанции, если применялся вообще. 
средневековье на два разных мировоззренческих периода: до середины VIII в. Саяно-Алтайское нагорье было вне зоны мировых религий, с 60-х гг. VIII в. в Древнехакасском государстве приняли манихейство, на столетия ставшее официальным вероисповеданием [Кызласов Л.Р., 1998; Кызласов И.Л., 2003а, с. 3-4 и библиография].

Писаницьь. В науке живут сомнения, когда появляются на Среднем Енисее наскальные рисунки - в позднем неолите или в раннем бронзовом веке. Так или иначе, но с тех пор петроглифы создавались непрерывно, включая этнографические культуры. Создание наскальных изображений всегда отражало существование горных культов.

В отличие от иных времен писаницы средневековья в ХакасскоМинусинской котловине не перекрывают петроглифы любого предшествующего периода. В IX-X вв. лично-фамильные тамги аристократов появляются на утесах, покрытых разновременными рисунками. Например, на Писанной горе [Appelgren-Kivalo, 1931, Abb. 66] или на скалах горы Тепсей, которую руны прямо называют божеством - $\boldsymbol{\uparrow} \boldsymbol{y} \mathbf{H}: \mathbf{9} \boldsymbol{\wedge} \mathbf{H}$ Tebsej tenri [Кызласов И.Л., 1992; 1994, с. 187]. Тамги выбиты среди, но лишь в соседстве с рисунками эпох ранней и развитой бронзы и раннего железа [Шер, 1980, рис. 72, 73; Blednova et al., 1995, pl. 26, 2.3, 2.8-2.11; $27,5.1-5.5 ; 46,21.1-21.5 ; 62,71.1]$ (рис. 4, a), иногда образуют ряды от 2-3 до 10 штук [Адрианов, 1904, л. 56, 63, 66 сл.; 1906]. Нанесение гербовых знаков можно объяснять поклонением горному божеству на издавна намоленном месте.
В ряде случаев тамги стоят, соотносясь с конкретным древним изображением или композицией [Шер, 1980, рис. 120, 1-3; Sher et al., 1994, fig. 21, 1, Oglakhty I, 10, 1-3, 5, 6]. Возможно, с уже бывшим на скале образом люди связывали свои чаяния, тамга указывала на человека, желавшего воплощения изображенного. Нанесение знака здесь также имело, по сути, молитвенный характер [Кызласов И.Л., 2014a, с. 54-56]. Неслучайно тамги двух поколений одной семьи выбиты над снаряженными конями, ведомыми антропоморфной фигурой - сценой раннего железного века (рис. 4, б, 1, 3). Судя по этапам развития тамг этой семьи, оглахтинскую геральдику надо относить к концу IX в. (ср.: [Кызласов Л.Р., 1965, рис. 1, 3-17; 7, 1]).

Вполне очевидно, что почитаться продолжают не только древние, но и ранние средневековые писаницы. Показательно размещение тамг IX-X вв. по сторонам изображений Сулекской писаницы [Appelgren-Kivalo, 1931, Abb. 77]. Вместе с иконографическими признаками эта особенность относит композиции этого памятника к предшествующему времени, т.е. к VIII в. [Кызласов И.Л., 1998 , с. 39-43].

С появлением на скалах тамг на писаницы наносят и краткие енисейские надписи. В ХакасскоМинусинской котловине они также никогда не вырезались поверх петроглифов. Строки идут выше или по краю поля с изображениями [Арpelgren-Kivalo, 1931, Abb. 77] (рис. 5) или извиваются меж фигур прошлых времен [Кызласов И.Л., 1994, рис. 21, $22,25 ; 2008$, рис. $2,4,5]$. На соседних землях Саяно-Алтая - в Тувинской котловине и на Горном Алтае наскаль- 


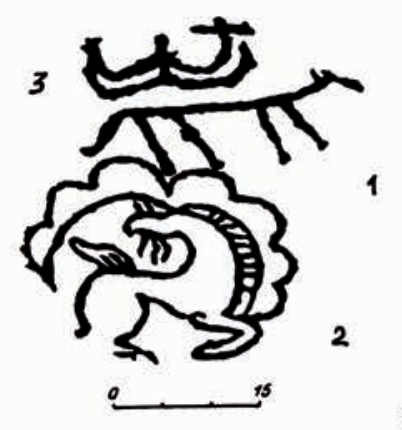

a

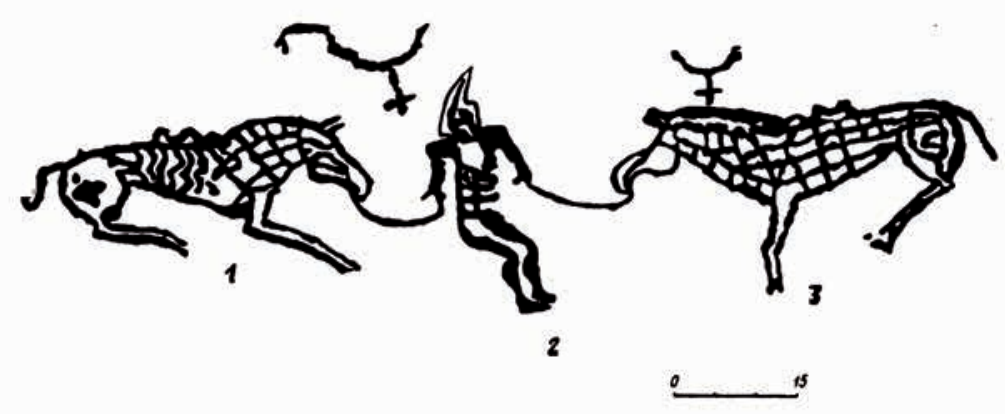

Pис. 4. Древнехакасские тамги на писаницах: а-гора Тепсей, пункт IV. Размещение тамги $I X-X$ вв. (3) у петроглифов эпохи бронзы (1) и раннего железного века (2) (no: [Blednova et al., 1995, pl. 27], с доработкой); б-гора Оглахты, пункт II. Композиция раннего железного века (1-3) и средневековые тамги $(1,3)$ (nо: [Шер, 1980 , рис. 120, 1-3], с доработкой]

Fig. 4. Ancient Khakassia tamgas in carvings: a-Mount Tepsei, item IV. Placement of tamga 9th-10th c. (3) at petroglyphs of the Bronze Age (1) and early Iron Age (2) (according to: [Blednova et al., 1995, pl. 27], with revision); b-Mount Oglakhty, item II. Composition of the Early Iron Age (1-3) and medieval tamgas (1, 3) (according to: [Sher, 1980], with revision]

ная эпиграфика размещается иначе, допуская перекрывание петроглифов древности, а иногда - и рисунков раннего средневековья [Кызласов И.Л., 2001 , рис. 2 ; 2003б, рис. $3,5,16 ; 2008$, рис. 6]. Вместе с тем, на Чуе есть примеры явного тяготения надписей к раннесредневековым изображениям при их сохранении [Кызласов, 2001, рис. 7 ; 2003б, рис. $17,21,23,28 ; 2008$, рис. 1].

С одной стороны, это указывает на смену форм горных культов - окончание рисуночного их выраже- ния и господство письменных и личных, геральдических молитвенных отметок. С другой - порождает мысль о Среднем Енисее как о центре появления такого вида поклонений, ставшего выражением именно сибирскотюркского, северного манихейства, разошедшегося в Центральной, части Средней Азии и Казахстане. До прихода этого обычая в землях восточного манихейства - в Восточном или в Западном Туркестане - практики молитвенных наскальных написаний не было [Кызласов И.Л., 2008, с. 452- 


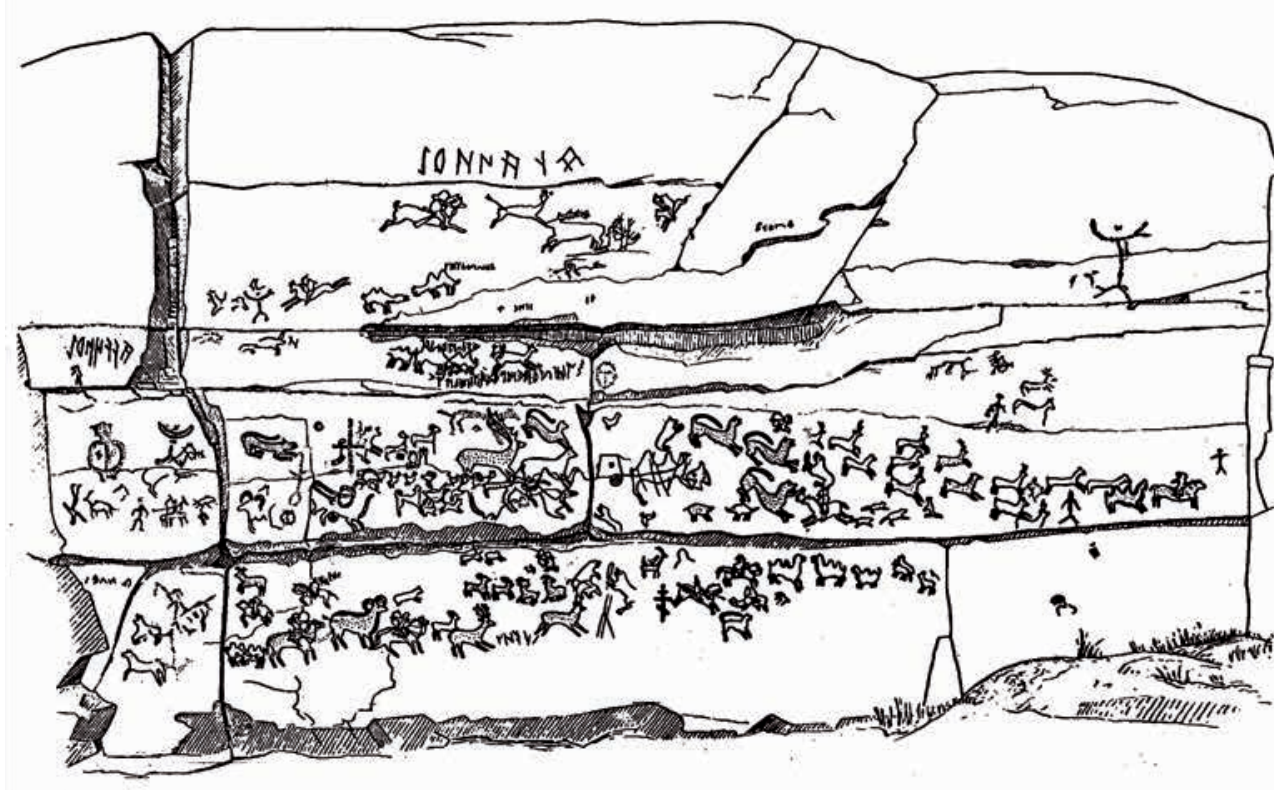

Рис. 5. Сулекская писаний. Расположение тамг и рунических надписей (no: [Appelgren-Kivalo, 1931, Abb. 77])

Fig. 5. Sulek carving. The location of tamgas and runic inscriptions (by: [Appelgren-Kivalo, 1931, Abb. 77])

457 ; 2013 a, c. $84 ; 2013 \mathbf{6} ; 2014$ a, c. $52-$ 57; Kyzlasov I., 2016].

Курганы. Могильники доманихейской поры - культуры VI - первой половины IX в. - получили название чаатасов (так именуется и сама культура того времени). Классический могильник-чаатас примыкает к погребальным памятникам двух предшествующих культур. Началом служит стоящий на восточном краю большой курган тесинского переходного этапа (традиционная дата: II-I вв. до н.э.), уходящим на запад продолжением служит кладбище таштыкской культуры, состоящее из нескольких коллективных, углубленных в землю склепов и множества грунтовых могил (традиционная дата: cep. I в. до н.э. $-\mathrm{V}$ в. н.э.). Затем рядами следуют курганы чаатас, меж которыми размещены округлые каменные насыпи.
Такое расположение на общем поле, вероятно, указывает на осознание кровнородственных связей с предками, присущее носителям этих трех культур, действительно прямо и тесно преемственно связанных между собою [Кызласов Л.Р., 1980, с. 110].

Сложенные из плитняка многогранные мавзолеи культуры чаaтас, подражающие бревенчатым наземным жилищам, по углам обставлялись высокими вертикальными стелами: 8, 10 или 12 [Кызласов Л.Р., 1980, с. 108 112 ; 1981 , с. $46-49$, рис. 28 , А-В, Д, Е, 1]. Символика их неясна, однако на некоторых могильниках, как на II Чаптыковском чаатасе, среди тёмных песчаниковых менгиров у каждого кургана одна из стел бывает светлой, серого гранита [Кызласов И.Л., 2019, рис. 7, 11]. Переиспользование на чаатасах изваяний древнейшей 
Кызласов И.Л. Восприятие последующими культурами памятников предыдущих...

поры (о которых шла речь в разделе 1) обычно. На каждом чаатасе их бывает несколько: на Уйбатском чаатасе, например, их 12, на Ташебинском - 9, на Абаканском - 4 и т.д. Нет сомнения, что перевозка этих изваяний из степи и водружение у свежевыстроенного мавзолея проводились намеренно.

На чатасах в каталоге древней скульптуры отмечен 51 случай использования таких монолитов [Леонтьев и др., 2006] (рис. 6). Среди менгиров одного кургана бывают два и даже три [Леонтьев и др., 2006, № 172-173, 252-253, 256-258] изваяния. Однажды оно было закопано вниз личиной [Леонтьев и др., 2006, № 201].

C принятием манихейства у курганов чаатас ставятся эпитафийные стелы енисейского рунического

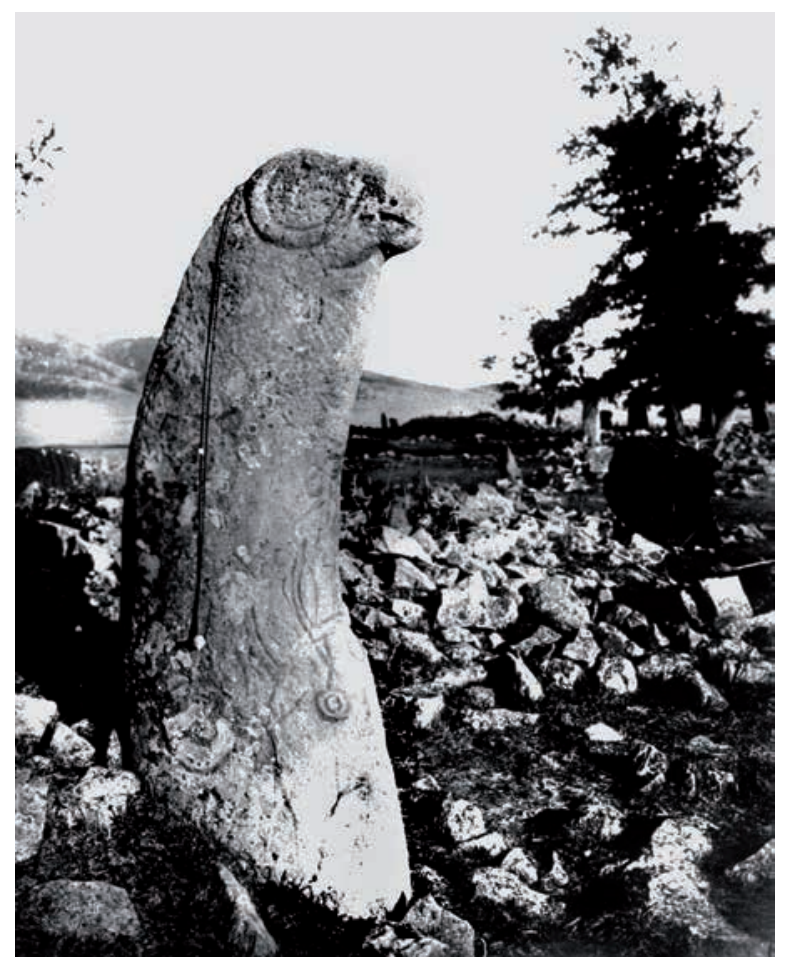

Рис. 6. Древнее изваяние на кургане Усть-Бюрьского (Чамакского) чаатаса. Фото Минусинского музея

Fig. 6. Ancient sculpture on the mound of Ust-Byur (Chamak) chaatas. Photo of the Minusinsk Museum письма. Традиция их установки передается древнехакасской тюхтятской культуре сер. IX - конца X в. и раннему этапу аскизской культуры - конец X - XI в. Обычай был массовым, ныне известно не менее 150 стел с надписями.

Поныне не обращалось внимания на очевидный для археолога факт: для енисейских эпитафий камни не добывали в каменоломнях и не обрабатывали. Всякий раз для памятной надписи были использованы только древние изваяния (рис. 7), оленные камни и менгиры, простоявшие в степях многие столетия, покрытые пустынным загаром, петроглифами и скульптурными изображениями раннего железного и бронзового веков или энеолита (менгиры со скошенными вершинами, см. фото: [Васильев, 1983, с. 82-114]). Именуемые «вечными» (N) $\mathbf{y}$ bejkü), енисейские эпитафии наносились на камни, которые средневековые хакасы связывали с вечностью своей земли [Кызласов И.Л., 2013а, c. 84-86; 2014б, с. 38-41].

Храм в котловине Сорга́. Изучая обнаруженные и раскопанные в Хакасии манихейские храмовые комплексы, в целом относящиеся к VIII - рубежу XIII вв. [Кызласов Л.Р., 1998, с. 15-27; 2001, с. 84-87], вновь встречаем особый, неожиданный род связи средневековых памятников с древностями предшествующих культур. Наиболее показательно расположение храма в котловине Сорга́.

В этой небольшой межгорной долине в разное 

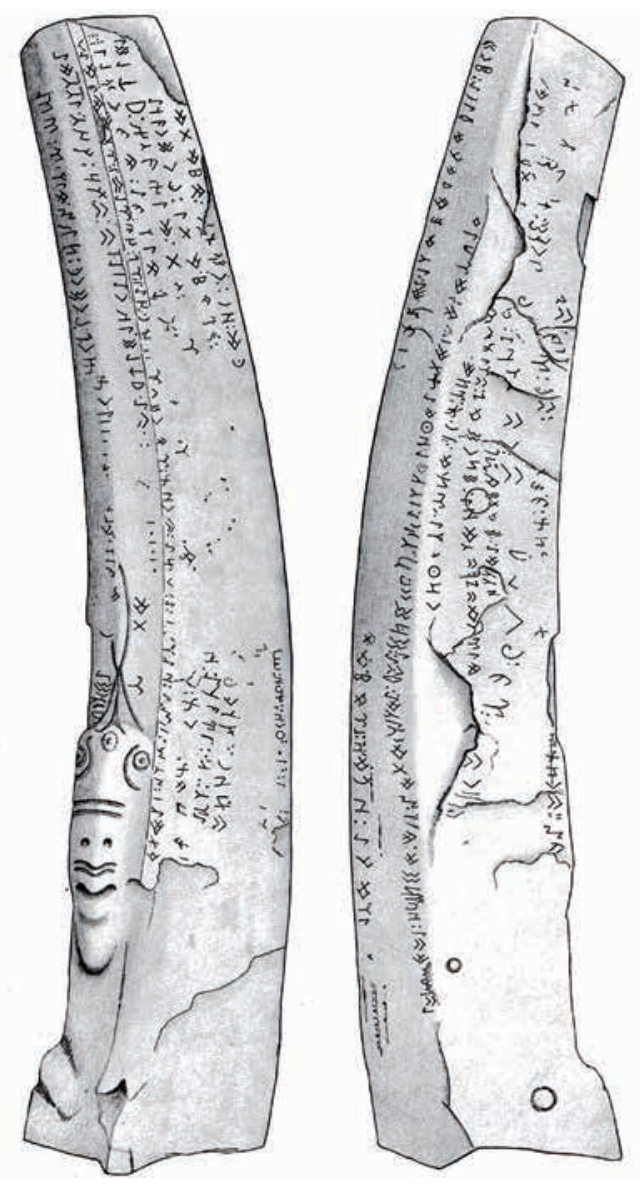

тов (включая шесть изваяний), выполнены рисунки изваяний и стел [Appelgren-Kivalo, 1931, s. 13, abb. 143-146]. Туда, как и в каталог монументальной скульптуры, менгиры, естественно, не вошли, но в сводке начала XXI в. были учтены 10 отдельно стоящих и четыре переиспользованных на тагарских курганах скульптур [Леонтьев и др., 2006].

Раскопки 1971 г. показали, что обе формы свободно стоящих монолитов - изваяния и менгиры - сохранились в местах первоначальной установки, имели единое культовое назначение и принадлежали к святилищам глубокой древности [Кызласов Л.Р., 1986, c. 98-151, 168-241].

В том же 1971 г. в долине, прямо на улице поселка ж/д ст. Ербинская были обнаружены руины манихейского храма VIII-X вв., которые были рас-

Рис. 7. Первый памятник енисейского письма (Уйбат III, E 32), открытый в августе 1721 2. Надпись перекрывает древнее изваяние (no: Appelgren-Kivalo, 1931, Abb. 156])

Fig. 7. The first monument of the Yenisey writing

(Uibat III, E 32), opened in August 1721. The inscription covers the ancient sculpture (according to: Appelgren-Kivalo, 1931, Abb. 156]) копаны в 1972-1973 гг. [Кызласов Л.Р., 1998, с. 26; 1999; 2001, с. 84] $]^{3}$. Культовое здание, знаменующее приход пророческой религии, несущей божественную истину, философски богатое мировоззрение с развитой книжной и обрядовой культу-

время отмечено 13 свободно стоявших изваяний и около 15 менгиров (рис. 8). Насколько знаю, они привлекли внимание науки в 1887 г., когда была составлена карта-схема окрестностей аала Тазмин с обозначением ряда памятников, планы-кроки части объек- рой, как и выстроенную церковную организацию, было размещено среди не потревоженного скопления каменных воплощений языческих взглядов и божеств 4000-летней давности (рис. 9). Это обстоятельство сразу обратило на себя внимание исследова-

${ }^{3}$ Ныне понятно, что Grossen Kurgan, отмеченный финской экспедицией [Appelgren-Kivalo, 1931, abb. 143], является бугром манихейского храма. 


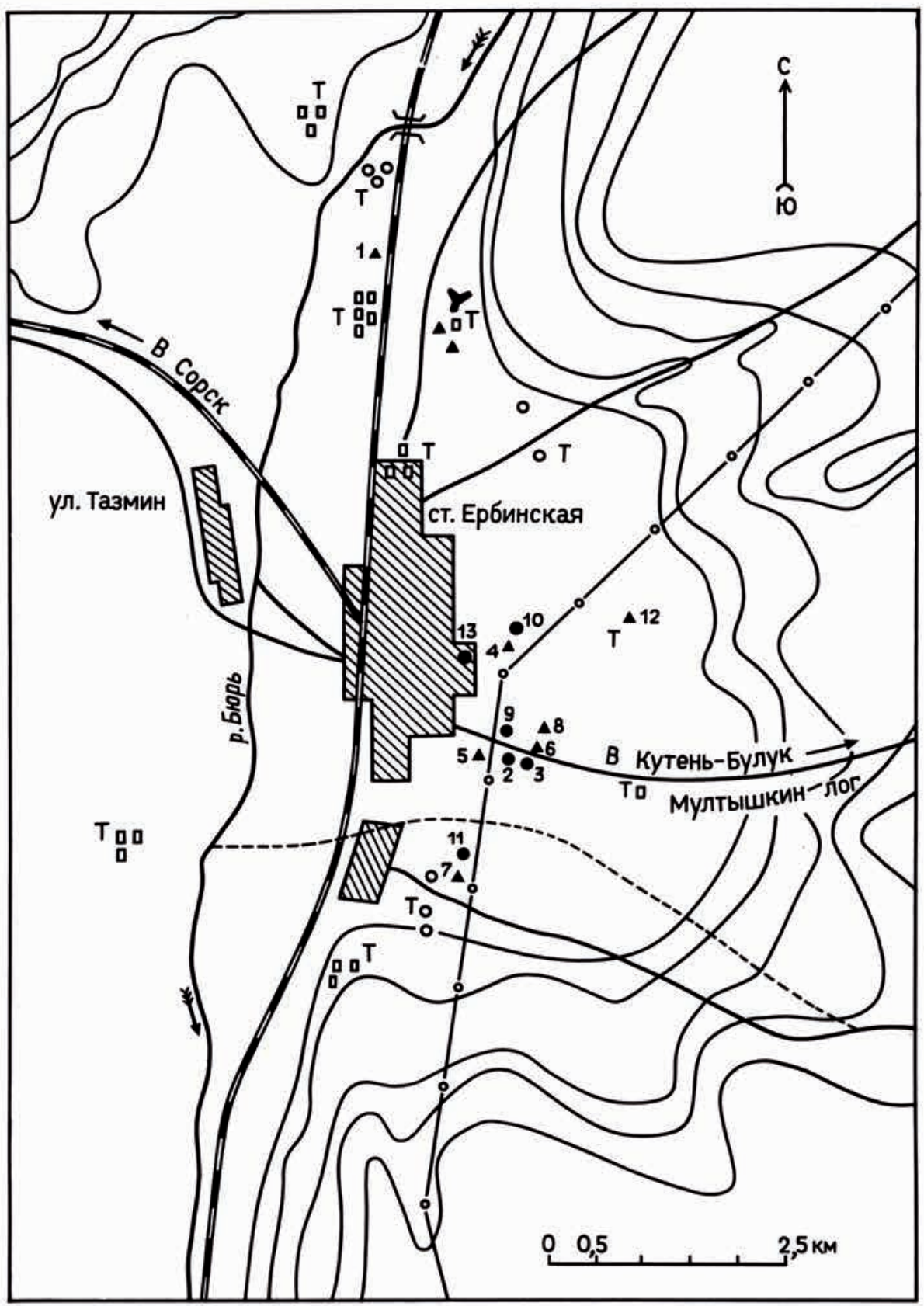

каменный курган

$\triangle$ изваяние

- менгир Іт тагарские курганы

Рис. 8. Расположение и номера памятников в котловине Сорга́ вокруг улуса Тазмина и ст. Ербинской. 1971 г. (по: [Кызласов Л.Р., 1986, рис. 30])

Fig. 8. Location and numbers of monuments in the basin of Sorgá around the Tazmin ulus and Yerbinskaya site. 1971 (by: [Kyzlasov L.R., 1986, Fig. 30]) 
теля, произведшего археологическое изучение обоих до того невиданных культурных явлений [Кызласов Л.Р., 1999, c. 181].

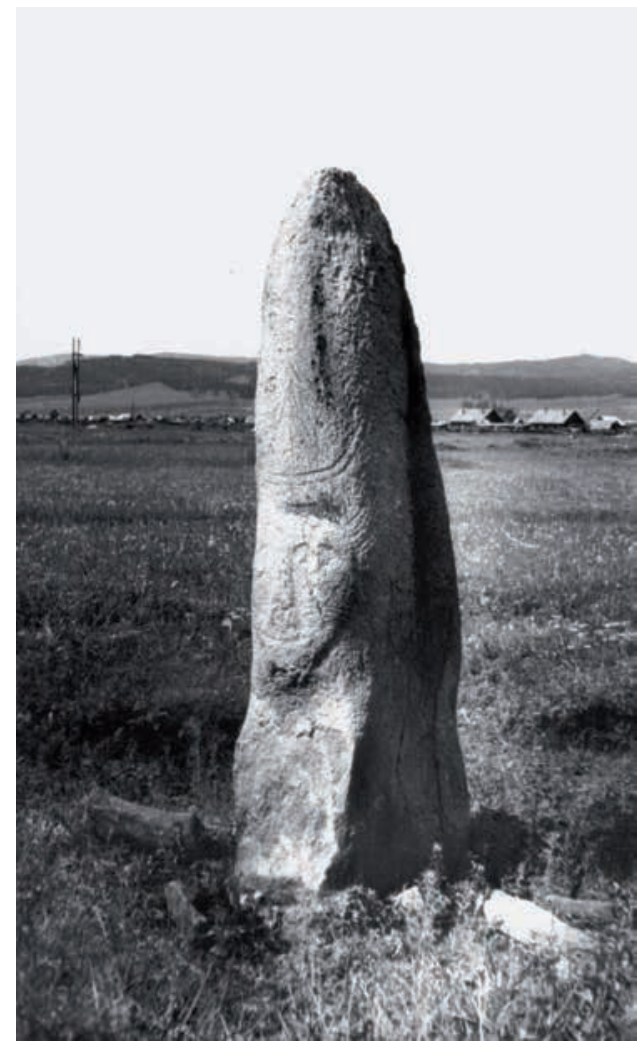

Рис. 9. Изваяние № 5 ввиду поселка Ербинское. За домами руины храма. 1971 г. Фото Л.Р. Кьзласова

Fig. 9. Sculpture No. 5 in view of the village of Yerbinsky. Behind the houses are the ruins of the temple. 1971 Photo by L.R. Kyzlasov

В 2019 г. нами получены новые данные, усиливающие необычность расположения средневекового храма. Короткой северо-западной стеной выходя на красную линию ул. Степной меж д. № 110 и 112, культовое здание вытянулось вдоль разделяющего усадьбы проулка, выходящего на ул. Боградскую и Промышленную (рис. 10). Ближайшее к храму изваяние № 13 находилось не далее 140 м к востоку. До 1958 г. оно стояло перед домом 23 по ул. Боградской, затем было повалено и к началу работ экспедиции МГУ 14 лет пролежало у забора усадьбы [Кызласов Л.Р., 1986, с. 146,147 , рис. 30,85$]$.

Полевой дневник Л. Р. Кызласова 1971 г. содержит об этом следующую запись (лл. 15-16): «10.VII вышло солнце и ездил на разведку <...> Проезжая по последней В[осточной] улице станции (Боградская № 23, хозяин Резаев С.И., узбек из Ферганы [, выслан в Сибирь] в 1938 г.), увидел стелу серого гранита, лежащую возле угла дома (длина 2,4 м). Она стояла до [л. 15] 1958 г. перед домом, а потом хозяин ее свалил и под ней в яме на глубине 1 м нашел [против этих слов на полях сделана дополнительная надпись «якобы,»- И.К.] 5-6 сосудов округлых (h до 15 см) и остатки 2-х дерев. ложек (теперь на ее месте в палисаднике стоит дерев. столб освещения) [л. 16]». Тем самым, изваяние 13 находилось близ проулка, соединяющего Боградскую и Степную улицу, по космоснимку не далее 140 м от юго-восточной стены и в 135 м от пандуса храма.

По прошествии 60 лет, следующим поколением владельцев этого дома (теперь имеющего № 57), Надеждой, дочерью В.И. и Н.И. Похабовых, изваяние было вновь водружено против дома посреди улицы (в 160 м от стен храма), окружено оградой, получило хакасское наименование $\mathrm{Ax}$ Хыс (Белая ( Светлая) девушка) и почитаемо [Кызласов И.Л., 2019, с. 32, рис. 17]. Перед нами одна из форм осознания русскими людьми Хакасии своей родиной и признания древностей этой земли своими. Мне извест- 
Кызласов И.Л. Восприятие последующими культурами памятников предыдущих...

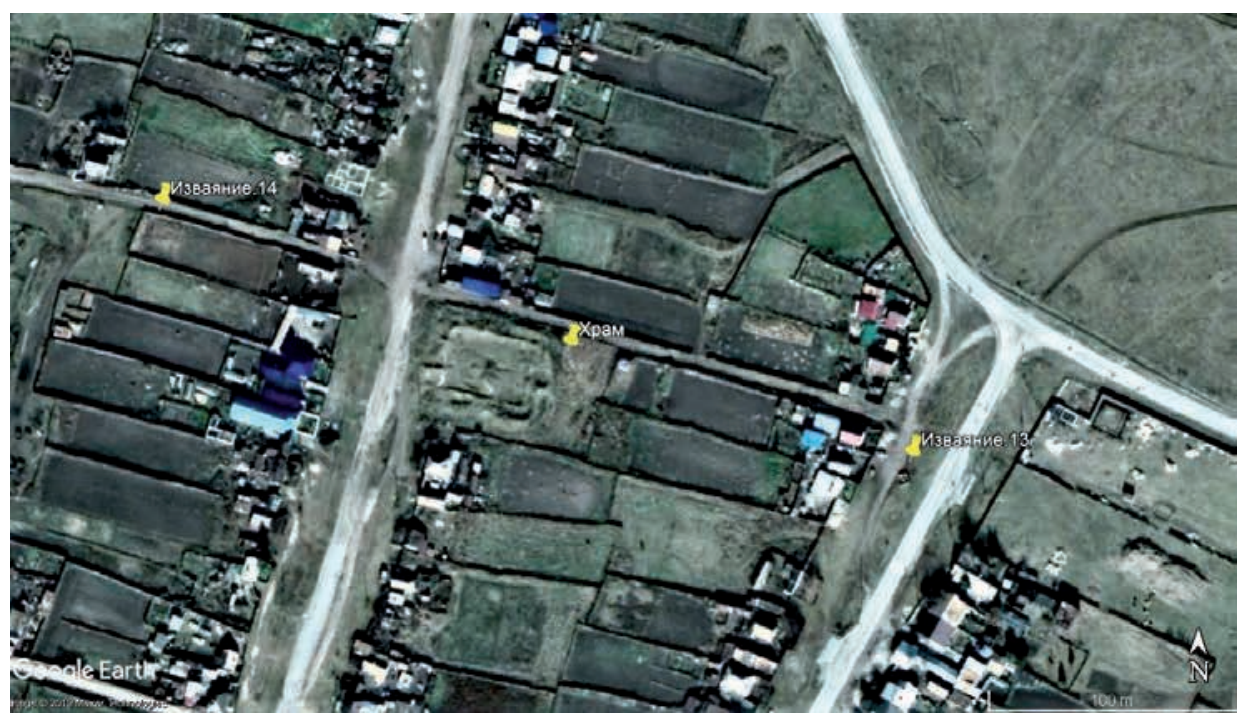

Рис. 10. Расположение манихейского храма (раскоп 1971-1972 г2.) и ближайших изваяний № 13 и 14 в поселке ст. Ербинская. 2019 г. Космоснимок

Fig. 10. The location of the Manichaean temple (excavation 1971-1972) and the nearest sculptures no. 13 and 14 in the village of Yerbinskaya site. 2019. Space image

но несколько примеров водружения упавших или ранее попранных изваяний и менгиров. Включение русских в культовую неопрактику хакасов во многом вызвано верой в заключенную в изваяниях жизненную энергию и плодоносную силу.

Такое отношение жителей поселка к памятникам привело к обнаружению ранее неизвестного 14-го изваяния котловины Сорга. У заднего забора усадьбы № 97 Степной улицы нам был указан лежащий монолит серого гранита общей длиною в 247 см. Округло обработанный, он утолщается к одному из концов до 46 см, а к другой, первоначально верхней, части сужается до 37 см.

Следовательно, манихейский храм был не только построен в долине, наполненной монументальными культовыми памятниками древности, он был возведен прямо среди извая- ний. К западу от него скульптура № 14 удалена на 110 м, а к востоку изваяние № 13 отстояло от входа в храм не далее 140 м (рис. 10). В енисейских эпитафиях времен Ербинского храма встречается мера длины, равная расстоянию полета стрелы - $\gg 33 \otimes 33$ > $<$ > oydamdam (E 51, 2, E 70, 3, E 109, 3, Е 110, 1) [Кызласов И.Л., 2003в, с. 284,$285 ; 2020$, с. 143,144$]$. Учитывая обычную дальность выстрела из сложного лука, в то время равную 200-250 м (в среднем 225 м) [Медведев, 1966, с. 30, 31], от стен храма до изваяний было только полперестрела. Если возьмем за меру длину прямоугольной платформы (41 м), на рост человека поднимавшей стены здания над землею, и почти пятиметровую протяженность ведущего к его входу пандуса (4,75 м) [Кызласов Л.Р., 1999, с. $181,185,187$, рис. 5], то станет ясно, что изваяние № 14 находилось немно- 
гим далее двух, а № 13 - трёх таких единиц. Иными словами, языческие кумиры остались нетронутыми, практически находясь на стройплощадке VIII в.

\section{Заключение}

Проследив по трем основным категориям культовых древностей раннего средневековья отношение к памятникам предыдущих культур Хакасско-Минусинской котловины, приходим к следующему заключению.

О чем свидетельствует намеренное использование давних изваяний на курганах доманихейской поры, сказать трудно. Нанесение эпитафий только на древние скульптуры и менгиры объясняется общими для восточнотюркских народов представлениями о первотворении мира и его изначальном каменном естестве, с которым сливается душа умершего: «из камня вышли и в камень уйдём». Однако само появление текстов, идущих от лица покойного, воплощенного в камне, происходит лишь с приходом письменной культуры манихейства. Ранние эпитафии стояли у юго-восточной стороны курганов (Ташебинский чаатас, E 40) [Heikel, 1912, s. 60, abb. 2, № 1], так же или к востоку ставились затем эпитафии в IX-XI вв. [Кызласов Л.Р., 1960, с. 98102, рис. 5]. Возможно, одна из еще бесписьменных юго-восточных стел мавзолеев чаатас символизировала умершего.

Уважительное отношение к древним писаницам свидетельствует о продолжавшемся существовании горных культов, первоначально по- рождавших создание раннесредневековых рисунков, а с приходом манихейства к их замене письменными и личными тамговыми отметками о совершенных молениях. Пример Ербинского храма, размещенного среди древних изваяний и менгиров в котловине Сорга́, указывает на уважительное отношение к ним даже при создании архитектурных богослужебных комплексов, где шли торжественные обряды, оглашались священные тексты, учившие отличать Добро и Зло, Свет и Мрак.

Известно, что манихейство имело универсальный характер, распространяло свое учение на языке обращаемого населения, в каждой стране приспосабливалось к господствовавшей там вере. Синкретизм являлся основой этой религии, проявлялся в отношении зороастризма, христианства, буддизма и иных исповеданий.

Достигнув Енисея, манихейство включило в свою религиозную практику бывшую там руническую письменность, а вместе с нею, как теперь видим, и весь основной комплекс традиционного мировосприятия, тесно связанного с почитанием памятников седой старины - будь то писаницы на скалах или стоявшие в долинах изваяния и менгиры. Енисейские руны соединили книжную природу храмов с культовой эпиграфикой горных святынь. Взаимное проникновение новой философии и давних местных верований сформировало новое религиозное направление - сибирско-тюркское (северное) манихейство, широко распространившееся как в Центральной, так и в Средней Азии и Казахстане. 
Кызласов И.Л. Восприятие последующими культурами памятников предыдущих...

\section{ЛИТЕРАТУРА}

1. Адрианов А.В. Писаницы (Отчеты за 1904 год), 1904. Рукопись // Архив Музея археологии и этнографии Сибири при Томском гос. университете. Инв. № 55, 191 л. Машинописная копия, личный архив Л.Р. Кызласова.

2. Адрианов А.В. Текст отчета А.В. Адрианова и таблицы к нему, 1906 // Архив Института археологии РАН, Р-ІІ, ф. 12 (Личный фонд С.В. Киселева), д. 151, 257 л.

3. Вадецкая Э.Б. Изваяния окуневской культуры // Вадецкая Э.Б., Леонтьев Н.В., Максименков Г.А. Памятники окуневской культуры. Л.: Наука, 1980. С. 37-90, 123147.

4. Васильев Д.Д. Корпус тюркских рунических памятников бассейна Енисея. Л.: Наука, 1983. 127 с.

5. Длужневская Г.В. Крепость Омайтура в Саянском каньоне Енисея // КСИА. 1989. Вып. 196. С. 93-98.

6. Киселёв С.В. К изучению минусинских каменных изваяний // Историкоархеологический сборник / Ред. Д.А. Авдусин, В.Л. Янин. М.: Изд. Московского ун-та, 1962. С. 53-61.

7. Кузьмин Н.Ю. О вторичном использовании окуневских изваяний // Проблемы изучения окуневской культуры: тез. докл. конф. СПб.: [б.и.], 1995. С. 55-57.

8. Кызласов И.Л. Поминальные памятники таштыкской эпохи // СА. 1975. № 2. C. $30-47$.

9. Кызласов И.Л. Семантика тагарского кургана // Исторические чтения памяти Михаила Петровича Грязнова: тез. обл. научн. конф. по разделам «Скифо-сибирская культурно-историческая общность. Раннее и позднее средневековье». Омск: [б.и.], 1987. C. 94-97.

10. Кызласов И.Л. Воплощения Вселенной (Археологические памятники как объект палеоастрономии) // Историко-астрономические исследования. М.: Наука, 1989. Вып. XXI. С. 193-212.

11. Кызласов И.Л. Древнехакасские надписи с названием горы Тепсей // Северная Евразия от древности до средневековья: тез. конф. к 90-летию со дня рождения М.П. Грязнова. СПб.: [б.и.], 1992. С. 220-221.

12. Кызласов И.Л. Рунические письменности евразийских степей. М.: Наука, 1994. $327 \mathrm{c}$.

13. Кьззласов И.Л. Изображение Тенгри и Умай на Сулекской писанице // ЭО. 1998. № 4. С. 39-53.

14. Кызласов И.Л. Смена мировоззрения в Южной Сибири в раннем средневековье (Идеи единобожия в енисейских надписях) // Древние цивилизации Евразии. История и культура / Отв. ред. А.В. Седов. М.: Вост. лит-ра РАН, 2001. С. 243-270.

15. Кызласов И.Л. Средневековая Евразия в свете новых открытий // КСИА. 2003a. Вып. 215. С. 3-6.

16. Кызласов И.Л. Новости тюркской рунологии. Вып. 1. Енисейские надписи на горе Ялбак-Таш (Горный Алтай). М.: Гуманитарий, 2003б. 112 с.

17. Кызласов И.Л. Местные речевые особенности енисейских надписей // Дешт-и Кипчак и Золотая Орда в становлении культуры евразийских народов: м-лы междунар. науч.-практ. конф. (г. Москва, 10-11 апреля 2003 г.). / Ред. Д.М. Насилов. М.: ИСАА при МГУ, 2003в. С. 283-286.

18. Кызласов И.Л. К уяснению исходных позиций изучения и сбережения писаниц // Человек, адаптация, культура / Отв. ред. А.Н. Сорокин. М.: ИА РАН, 2008. C. $451-463$.

19. Кызласов И.Л. Алтаистика и археология. М.: Ин-т тюркологии, 2011. 256 с.

20. Кызласов И.Л. Религиозная природа енисейской письменности. I // РТ. 2013а. № 2. C. 79-90. 
21. Кызласов И.Л. Руническое письмо на скалах: сибирские корни обряда и его распространение в Средней Азии // Культурный трансфер на перекрестках Центральной Азии: до, во время и после Великого Шелкового пути. Париж-Самарканд: МИЦАИ, 2013б. С. 116-121.

22. Кызласов И.Л. Религиозная природа енисейской письменности. II // РТ. 2014a. № 1. C. 52-61.

23. Кызласов И.Л. Сотворение мира глазами пратюрков (рунологические и археологические приметы) // Проблемы востоковедения. 2014б. № 2 (64). С. 35-41.

24. Кызласов И.Л. Задачи археологического изучения Хакасско-Минусинской котловины. Абакан: Бригантина, 2019. 40 с.

25. Кызласов И.Л. Опасность современного письма рунами тюрков // Вопросы тюркской филологии: м-лы Дмитриевских чтений. М.: Изд-во МБА, 2020. Вып. ХІІІ. C. $133-154$.

26. Кызласов Л.Р. Новая датировка памятников енисейской письменности // СА. 1960. № 3. С. 93-120.

27. Кызласов Л.Р. Начало сибирской археологии // Историко-археологический сборник / Ред. Д.А. Авдусин, В.Л. Янин. М.: Изд. МГУ, 1962. С. 43-52.

28. Кьззласов Л.Р. О датировке памятников енисейской письменности // СА. 1965. № 3. C. 38-49.

29. Кызласов Л.Р. Древние крепости Хакасии // АО-1968. М.: Наука, 1969. C. 244-246.

30. Кызласов Л.Р. Раскопки в Оглах-тах // АО-1969. М.: Наука, 1970. С. 197-199.

31. Кызласов Л.Р. Чаатасы Хакасии // Вопросы археологии Хакасии / Отв. ред. Я.И. Сунчугашев. Абакан: [б.и.], 1980. С. 108-114.

32. Кызласов Л.Р. Древнехакасская культура чаатас VI-IX вв. // Археология СССР. Степи Евразии в эпоху средневековья / Отв. ред. Б.А. Рыбаков. М.: Наука, 1981. С. 46-52. Рис. 28, 29.

33. Кьззласов Л.Р. Древнейшая Хакасия. М.: Изд. Московского ун-та, 1986. 295 с.

34. Кызласов Л.Р. Святилища каменного века // Вторые исторические чтения памяти М.П. Грязнова. Омск: [б.и.], 1992. Ч. 2. С. 51-54.

35. Кызласов Л.Р. Северное манихейство и его роль в культурном развитии народов Сибири и Центральной Азии // ВМУ. 1998. Серия 8. История. № 3. С. 8-35.

36. Кызласов Л.Р. Манихейский храм в котловине Сорга (Республика Хакасия) // PA. 1999. № 2. С. 181-206.

37. Кызласов Л.Р. Сибирское манихейство // ЭО. 2001. № 5. С. 83-90.

38. Кызласов Л.Р. Отчет о работе Хакасской археологической экспедиции МГУ в 1968 г. // НОА ИА РАН. М.: ИА РАН, 2017а. Т. 5. С. 241-242.

39. Кызласов Л.Р. Отчет о работе Хакасской археологической экспедиции МГУ в 1969 г. // НОА ИА РАН. М.: ИА РАН, 2017б. Т. 5. С. 131-132.

40. Леонтьев Н.В. Гравированные изображения животных в могильнике Черновая VIII // Э.Б. Вадецкая, Н.В. Леонтьев, Г.А. Максименков. Памятники окуневской культуры. Л.: Наука, 1980. С. 27-34, 88-90, 121, 122.

41. Леонтьев Н.В., Капелько В.Ф., Есин Ю.Н. Изваяния и стелы окуневской культуры. Абакан: Хакасское кн. изд-во, 2006. 236 с.

42. Медведев А.Ф. Ручное метательное оружие. (Лук и стрелы, самострел). VIIIXIV вв. / САИ. Вып. Е1-36. М.: Наука, 1966. 184 с.

43. Подольский М.Л. Овладение бесконечностью (опыт типологического подхода к окуневскому искусству) // Окуневский сборник. Культура. Искусство. Антропология. СПб.: Петро-РИФ, 1997. С. 168-201.

44. Подольский М.Л. Све Чиланныг тах на севере Хакасии // Евразия сквозь века / Отв. ред. И.Я. Фроянов, С.Н. Астахов. СПб.: Филолог. ф-т СПб гос. ун-та, 2001. С. $108-110$. 
Кызласов И.Л. Восприятие последующими культурами памятников предыдущих...

45. Подольский М.Л. Каменный городок Чиланных таг // А.И. Готлиб, М.Л. Подольский. Све - горные сооружения Минусинской котловины. СПб.: [б.и.], 2008. C. $115-187$.

46. Поляков А.В. Радиоуглеродные даты окуневской культуры // ЗИИМК. 2017. № 16. C. 52-74.

47. Поляков А.В. Радиоуглеродные даты памятников андроновской (фёдоровской) культуры на Енисее // ЗИИМК. 2019. № 20. С. 163-173.

48. Поляков А.В., Святко С.В. Радиоуглеродное датирование археологических памятников неолита - начала железного века Среднего Енисея: обзор результатов и новые данные // ТиПАИ. 2009. № 5. С. 20-56.

49. Савинов Д.Г. Памятники археологии Сибири в материалах Д.Г. Мессершмидта // Тункина И.В., Савинов Д.Г. Даниил Готлиб Мессершмидт. У истоков сибирской археологии. СПб.: ЭлекСис, 2017. С. 74-134.

50. Соколова Л.А. Проблема сложения окуневской культуры // Проблемы изучения окуневской культуры: тез. докл. конф. СПб.: [б.и.], 1995. С. 20-24.

51. Соколова Л.А. Окуневская культурная традиция в стратиграфическом аспекте // АЭАЕ. 2007. № 2. С. 41-51.

52. Соколова Л.А. Формирование окуневского культурного комплекса: автореф. дис. ... канд. ист. наук. СПб.: ИИМК РАН, 2009. 23 с.

53. Соколова Л.А. Формирование окуневского культурного комплекса. Саарбрюккен, 2011. 335 c. URL: https://independent.academia.edu/ЛюдмилаСоколова

54. Филиппова E.E. Карасукские могилы в горах Оглахты (Хакасия) // ВМУ. 1974. Серия IX. История. № 2. С. 86-93.

55. Филиппова Е.Е. Погребальная колесница карасукского времени // Проблемы изучения наскальных изображений в СССР. М.: ИА АН СССР, 1990. С. 166-168.

56. Шер Я.А. Петроглифы Средней и Центральной Азии. М.: Наука, 1980. $328 \mathrm{c}$.

57. Шер Я.А. Была ли окуневская культура // Окуневский сборник 2. Культура и ее окружение / Ред. коллегия: Д.Г. Савинов и др. СПб., 2006. С. 248-250.

58. Appelgen-Kivalo H. Alt-Altaische Kunstdenkmäler. Helsingfors: K.F. Puromies Buchdruckerei A.-G., 1931. 119 s.

59. Blednova N., Francfort H.-P., Legtchilo N., Martin L., Sacchi D., Sher J.A., Smirnov D., Soleilhavoup F., Vidal P. Sibérie du Sud 2: Tepsej I-III, Ust'-Tuba I-VI (Russie, Khakassie) // Répertoire des Pétroglyphes d'Asie Centrale, fasc. 2 (Mémoires de la Mission Archéologique Francaise en Asie Centrale. T. V, 2). Paris: Diffusion du Boccard, 1995. $68+$ LXXVII + 93 p.

60. Heikel A.O. Die Grabuntersuchungen und Funde bei Tashebá // Zeitschrift der Finnischen Altertumsgesellschaft. Helsinki, 1912. XXVI. S. 59-70.

61. Kyzlasov I. Inscriptions rupestres runiques. De la Sibérie à l'Asie centrale et au Kazahstan // Asie centrale. Transferts culturels le long de la route de la soie. Paris: Vendémiaire, 2016. P. 301-307.

62. Sher J., Blednova N., Legtchilo N., Smirnov D. Sibérie du Sud 1: Oglakhty I-III (Russie, Khakassie) // Répertoire des Pétroglyphes d'Asie Centrale, fasc. 1 (Mémoires de la Mission Archéologique Francaise en Asie Centrale. T. V, 1). Paris: Diffusion du Boccard, 1994. 4+52+XXXVIII+80 p.

\section{REFERENCES}

1. Adrianov, A. V. 1904. In: Arhiv Muzeya arheologii i etnografii Sibiri pri Tomskom gosuniversitete. Inv. № 55. Mashinopisnaya kopiya, lichnyi arhiv L.R. Kyzlasova (Archive 
of the Museum of Archeology and Ethnography of Siberia near the Tomsk State University. No. 55. Copy from the personal archive of L.R. Kyzlasov) (in Russian).

2. Adrianov, A. V. 1906. In: Arhiv Instituta arheologii RAN, R-II, f. 12 (Lichnyi fond S. V. Kiseleva), d. 151 (Archives of the Institute of Archeology of the RAS, P-II, f. 12 (Personal fund of S. V. Kiselev), d. 151) (in Russian).

3. Vadetskaya, E. B. 1980. In: Vadetskaya, E. B., Leontiev, N. V., Maksimenkov, G. A. Pamyatniki okunevskoy kultury (The monuments of the Okunev culture). Leningrad: "Nauka" Publ., 37-90, 123-147 (in Russian).

4. Vasiliev, D. D. 1983. Korpus tyurkskih runicheskih pamyatnikov basseyna Eniseya (Corps of Turkic runic monuments of the Yenisey basin). Leningrad: "Nauka" Publ. (in Russian).

5. Dluzhnevskaya, G. V. 1989. In: Kratkie soobshcheniya Instituta archeologii (Brief reports of the Institute of Archeology), 196, 93-98 (in Russian).

6. Kiselyov, S. V. 1962. In: Avdusin, D. A., Yanin, V. L. Istoriko-arheologicheskiy sbornik (Historical and archaeological collection). Moscow: Moscow University, 53-61 (in Russian).

7. Kuzmin, N. YU. 1995. In: Problemy izucheniya okunevskoy kultury (Problems of studying the Okunev culture). Saint Petersburg, 55-57 (in Russian). Russian).

8. Kyzlasov, I. L. 1975. In: Sovetskaya arheologiya (Soviet archeology), 2, 30-47 (in

9. Kyzlasov, I. L. 1987. In: Istoricheskie chteniya pamyati M.P. Gryaznova (Historical readings in memory of Mikhail P. Gryaznov). Omsk, 94-97 (in Russian).

10. Kyzlasov, I. L. 1989. In: Istoriko-astronomicheskie issledovaniya (Historical and astronomical research), vol. 21. Moscow: "Nauka" Publ., 193-212 (in Russian).

11. Kyzlasov, I. L. 1992. In: Severnaya Evraziya ot drevnosti do srednevekoviya (Northern Eurasia from antiquity to the Middle Ages). Saint Petersburg, 220-221 (in Russian).

12. Kyzlasov, I. L. 1994. Runicheskie pismennosti evraziyskih stepey (Runic scripts of the Eurasian steppes). Moscow: "Nauka" (in Russian).

13. Kyzlasov, I. L. 1998. In: Etnograficheskoe obozrenie (Ethnographic review), 4, 39-53 (in Russian).

14. Kyzlasov, I. L. 2001. In: Sedov, A. V. (ed.). Drevnie civilizacii Evrazii. Istoriya $i$ kultura (Ancient civilizations of Eurasia. History and culture). Moscow: "Vostochnaya literature" Publ., 243-270. (in Russian).

15. Kyzlasov, I. L. 2003a. In: Kratkie soobshcheniya Instituta archeologii (Brief reports of the Institute of Archeology), 215, 3-6 (in Russian).

16. Kyzlasov, I. L. 2003b. Novosti tyurkskoy runologii. Vyp. 1. Eniseyskie nadpisi na gore Yalbak-Tash (Gornyi Altay) (News of the Turkic runology. Issue 1. Yenisey inscriptions on Yalbak-Tash mountain (Altay Mountains). Moscow: "Gumanitariy" Publ. (in Russian).

17. Kyzlasov, I. L. 2003 c. In: Nasilov, D. M. (ed.). Desht-i Kipchak i Zolotaya Orda $v$ stanovlenii kultury evraziyskih narodov (Desht-i Kipchak and the Golden Horde in the formation of the culture of the Eurasian peoples). Moscow: Moscow State University, 283286 (in Russian).

18. Kyzlasov, I. L. 2008. In: Sorokin, A. N. (ed.). Chelovek, adaptaciya, kultura (Man, adaptation, culture). Moscow: Institute of Archeology RAS, 451-463 (in Russian).

19. Kyzlasov, I. L. 2011. Altaistika i arheologiya (Altaistics and Archeology). Moscow: Institute of tyurkology (in Russian). (in Russian).

20. Kyzlasov, I. L. 2013a. In: Rossiyskaya tyurkologiya (Russian turkology), 2, 79-90

21. Kyzlasov, I. L. 2013b. In: Kulturnyi transfer na perekrestkah Centralnoy Azii: do, vo vremya i posle Velikogo Shelkovogo puti (Cultural transfer at the crossroads of Central Asia: before, during and after the Great Silk Road). Parise-Samarkand: International Institute for Central Asian Studies, 116-121 (in Russian).

22. Kyzlasov, I. L. 2014a. In: Rossiyskaya tyurkologiya (Russian turkology), 1, 52-61 (in Russian). 
Кызласов И.Л. Восприятие последующими культурами памятников предыдущих...

23. Kyzlasov, I. L. 2014b. In: Problemy vostokovedeniya (Problems of Oriental Studies), 2 (64), 35-41 (in Russian).

24. Kyzlasov, I. L. 2019. Zadachi arheologicheskogo izucheniya HakasskoMinusinskoy kotloviny (Tasks of archaeological study of the Khakass-Minusinsk depression). Abakan: "Brigantina" (in Russian).

25. Kyzlasov, I. L. 2020. In: Voprosy tyurkskoy filologii (Questions of the Turkic philology), 13. Moscow: "MBA" Publ., 133-154 (in Russian).

26. Kyzlasov, L. P. 1960. In: Sovetskaya arheologiya (Soviet archeology), 3, 93-120 (in Russian).

27. Kyzlasov, L. R. 1962. In: Avdusin, D. A., Yanin, V. L. (eds.). Istorikoarheologicheskiy sbornik (Historical and archaeological collection). Moscow: Moscow State University, 43-52 (in Russian). Russian).

28. Kyzlasov, L. R. 1965. Sovetskaya arheologiya (Soviet archeology), 3, 38-49 (in

29. Kyzlasov, L. R. 1969. In: Arheologicheskie otkrytiya-1968 (Archaeological discoveries-1968). Moscow: "Nauka", 244-246 (in Russian).

30. Kyzlasov, L. R. 1970. In: Arheologicheskie otkrytiya-1969 (Archaeological discoveries-1969. Moscow: "Nauka", 197-199 (in Russian).

31. Kyzlasov, L. R. 1980. In: Sunchugashev, Ya. I. (ed.). Voprosy arheologii Hakasii (Questions of archeology of Khakassia). Abakan, 108-114 (in Russian).

32. Kyzlasov, L. R. 1981. In: Rybakov, B. A. (ed.). Arheologiya SSSR. Stepi Evrazii $v$ epohu srednevekoviya (Archeology of the USSR. Steppes of Eurasia in the Middle Ages). Moscow: "Nauka", 46-52, fig. 28, 29 (in Russian).

33. Kyzlasov, L. R. 1986. Drevneyshaya Hakasiya (The ancient Khakassia). Moscow: Moscow University (in Russian).

34. Kyzlasov, L. R. 1992. In: Vtorye istoricheskie chteniya pamyati M.P. Gryaznova (Second historical readings in memory of M. P. Gryaznov). Omsk, part 2, 51-54 (in Russian).

35. Kyzlasov, L. R. 1998. In: Vestnik Moskovskogo universiteta (Moscow University Bulletin), 3, 8-35 (in Russian).

36. Kyzlasov, L. R. 1999. In: Rossiyskaya arheologiya (Russian archeology), 2, 181206 (in Russian).

37. Kyzlasov, L. R. 2001. In: Etnograficheskoe obozrenie (Ethnographic review), 5, 83-90 (in Russian).

38. Kyzlasov, L. R. 2017a. In: Nauchno-otraslevoy arhiv Instituta arheologii RAN (Scientific archive of the Institute of Archeology of the RAS). Moscow: Institute of Archeology of the RAS, vol. 5, 241-242 (in Russian).

39. Kyzlasov, L. R. 2017b. In: Nauchno-otraslevoy arhiv Instituta arheologii RAN (Scientific archive of the Institute of Archeology of the RAS). Moscow: Institute of Archeology of the RAS, vol. 5, 131-132 (in Russian).

40. Leontiev, N. V. 1980. In: Vadetskaya, E. B., Leontiev, N. V., Maksimenkov, G. A. Pamyatniki okunevskoy kultury (Monuments of Okunev culture). Leningrad: "Nauka", 27-34, 88-90, 121, 122 (in Russian).

41. Leontiev, N. V., Kapelko, V. F., Esin, Yu. N. 2006. Izvayaniya i stely okunevskoy kultury (Statues and steles of the Okunev culture). Abakan: Hakasskoe knizhnoe izdatelstvo (in Russian).

42. Medvedev, A. F. 1966. Ruchnoe metatelnoe oruzhie (Hand throwing weapons). Moscow: "Nauka" (in Russian).

43. Podolskiy, M. L. 1997. In: Okunevskiy sbornik. Kultura. Iskusstvo. Antropologiya (Okunev Collection. Culture. Art. Anthropology). Saint Petersburg: "Petro-RIF", 168-201 (in Russian).

44. Podolskiy, M. L. 2001. In: Froyanov, I. Ya., Astakhov, S. N. Evraziya skvoz veka (Eurasia through the ages). Saint Petersburg: Philology faculty of the Saint Petersburg State University, 108-110 (in Russian). 
45. Podolskiy, M. L. 2008. In: Gotlib, A. I., Podolskiy, M. L. Sve-gornye sooruzheniya Minusinskoy kotloviny (Sve - mountain structures of the Minusinsk depression). Saint Petersburg, 115-187 (in Russian).

46. Polyakov, A. V. 2017. In: Zapiski Instituta istorii materialnoy kultury (Transactions of the Institute for the History of Material Culture), 16, 52-74 (in Russian).

47. Polyakov, A. V. 2019. Zapiski Instituta istorii materialnoy kultury (Transactions of the Institute for the History of Material Culture), 20, 163-173 (in Russian).

48. Polyakov, A. V., Svyatko, S. V. 2009. In: Theory and practice of the archaeological researches, 5, 20-56 (in Russian).

49. Savinov, D. G. 2017. In: Tunkina, I. V., Savinov, D. G. Daniil Gotlib Messershmidt. $U$ istokov sibirskoy arheologii (Daniel Gottlieb Messerschmidt. At the origins of Siberian archeology). Saint Petersburg: "ElekSis" Publ., 74-134 (in Russian).

50. Sokolova, L. A. 1995. In: Problemy izucheniya okunevskoy kultury (Problems of the study of the Okunev culture). Saint Petersburg, 20-24 (in Russian).

51. Sokolova, L. A. 2007. In: Archaeology, ethnology and anthropology of Eurasia, 2, 41-51 (in Russian).

52. Sokolova, L. A. 2009. Formirovanie okunevskogo kulturnogo kompleksa: avtoref. diss. ... kand. ist. nauk (Formation of the Okunev cultural complex: thesis of the Candidate historical sciences). Saint Petersburg: Institute for the History of Material Culture RAS (in Russian).

53. Sokolova, L. A. 2011. Formirovanie okunevskogo kulturnogo kompleksa (Formation of the Okunev cultural complex: thesis of the Candidate historical sciences). Saarbryukken. URL: https://independent.academia.edu/LyudmilaSokolova (in Russian).

54. Filippova, E. E. 1974. In: Vestnik Moskovskogo universiteta (Moscow University Bulletin), 2, 86-93 (in Russian).

55. Filippova, E. E. 1990. In: Problemy izucheniya naskalnyh izobrazheniy v SSSR (Problems of studying rock carvings in the USSR). Moscow: Institute of Archeology AS USSR, 166-168 (in Russian).

56. Sher, Ya. A. 1980. Petroglify Sredney i Centralynoy Azii (Petroglyphs of Central and Central Asia). Moscow: "Nauka" Publ. (in Russian).

57. Sher, Ya. A. 2006. In: Savinov, D. G. et al. (eds.). Okunevskiy sbornik 2. Kultura i ee okruzhenie (Okunev collection 2. Culture and its environment). Saint Petersburg, 248-250 (in Russian).

58. Appelgen-Kivalo, H. 1931. Alt-Altaische Kunstdenkmäler. Helsingfors: K.F. Puromies Buchdruckerei A.-G.

59. Blednova, N., Francfort, H.-P., Legtchilo, N., Martin, L., Sacchi, D., Sher, J.A., Smirnov, D., Soleilhavoup, F., Vidal, P. 1995. In: Répertoire des Pétroglyphes d'Asie Centrale, fasc. 2 (Mémoires de la Mission Archéologique Francaise en Asie Centrale. T. V, 2). Paris: Diffusion du Boccard.

60. Heikel, A. O. 1912. In: Zeitschrift der Finnischen Altertumsgesellschaft. Helsinki, XXVI, 59-70.

61. Kyzlasov, I. 2016. In: Asie centrale. Transferts culturels le long de la route de la soie. Paris: Vendémiaire, 301-307.

62. Sher, J., Blednova, N., Legtchilo, N., Smirnov, D. 1994. In: Répertoire des Pétroglyphes d'Asie Centrale, fasc. 1 (Mémoires de la Mission Archéologique Francaise en Asie Centrale. T. V, 1). Paris: Diffusion du Boccard.

\footnotetext{
Мүдделер қақтығысы туралы ақпаратты ашу. Автор мүдделер қақтығысының жоқтығын мәлімдейді.

/ Раскрытие информации о конфликте интересов. Автор заявляет об отсутствии конфликта интересов.

/ Disclosure of conflict of interest information. The author claim no conflict of interest.

Мақала туралы ақпарат / Информация о статье / Information about the article.

Редакцияға түсті / Поступила в редакцию / Entered the editorial office: 09.09.2020.

Рецензенттер мақұлдаған / Одобрено рецензентами / Approved by reviewers: 10.08.2020.

Жариялауға қабылданды / Принята к публикации / Accepted for publication: 20.08.2020.
} 